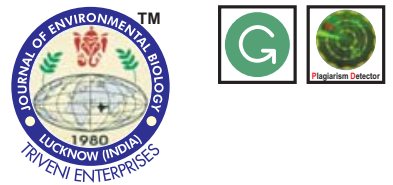

\title{
Effect of nitrogen on starch and protein content in grain influence of nitrogen doses on grain starch and protein accumulation in diversified wheat genotypes
}

\section{Authors Info}

B. Asthir ${ }^{1 *}$, D. Jain ${ }^{1}$, B. Kaur and N.S. Bains ${ }^{2}$

'Department of Biochemistry, Punjab Agricultural University, Ludhiana-141 004, India

${ }^{2}$ Department of Plant Breeding and Genetics, Punjab Agricultural University, Ludhiana-141 004, India

${ }^{*}$ Corresponding Author Email : b.asthir@rediffmail.com

Key words

Amino acids,

Grain quality parameters,

Nitrogen doses,

Triticum aestivum

Publication Info

Paper received : 19.09 .2015

Revised received : 16.04.2016

Re-revised received : 16.07 .2016

Accepted: 05.08 .2016
Abstract

Aim: Nitrogen is a critical input involved in plant metabolism growth and in different biochemical processes. Nitrogen participates directly in amino acid, protein and other cellular component syntheses, which are required for plant growth and development. Therefore, nitrogen application greatly influences starch and protein composition and, very little information is available on the effect of nitrogen fertilizer on protein sub fractions and starch components with little emphasis on quality characteristics. Therefore, the aim of the study was to evaluate the genotypic variation based on starch and protein accumulation under different doses of nitrogen.

Methodology: The present study was conducted to evaluate the effect of different doses of nitrogen in form of urea on grain quality parameters such as protein sub-fractions, starch sub-components from nine wheat genotypes (PBW 621, PBW 590, PBW 509, BW 9183, BW 8989, PBW 550, GLU 1101, GLU 1356, PH 132 4836) at four levels of nitrogen ( $\mathrm{N}$ ) optimal $\mathrm{N}$ dose i.e., recommended dose of $\mathrm{N}[\mathrm{RDN}(120 \mathrm{Kg} \mathrm{N}$ ha')], suboptimal $\mathrm{N}$ dose $\left[\mathrm{RDN}-25 \%\left(90 \mathrm{Kg} \mathrm{N}^{-1} \mathrm{a}^{-1}\right)\right]$ and supra-optimal $\mathrm{N}$ doses $\left[\mathrm{RDN}+25 \%\left(150 \mathrm{Kg} \mathrm{N}^{-{ }^{-1}}\right)\right.$ and $\mathrm{RDN}+50 \%$ (180 Kg N ha-1)].

Results: PBW 550, BW 8989 and BW 9183 genotypes had higher sugars content ( $20 \mathrm{mg} \mathrm{g}^{-1}$ d.wt.) and starch $(\sim 72.8 \%)$, whereas amino acids and protein content were low $\left(\sim 0.65-100.3 \mathrm{mg} \mathrm{g}^{-1}\right.$ d.wt., respectively). Sugar and starch content were inversely correlated with protein and amino acids indicating a compensatory effect. Higher build-up of grain protein in GLU $1101\left(126.3 \mathrm{mg} \mathrm{g}^{-1}\right.$ DW) and GLU 1356 (141.7 $\mathrm{mg} \mathrm{g}^{-1}$ d.wt.) might be due to higher translocation of $\mathrm{N}$ from flag leaf to reproductive structures. Gluten constituted major seed storage proteins as its content was comparatively higher over other proteins in genotypes- PBW 590 and PH-132-4836 ( $\sim 51.7 \mathrm{mg} \mathrm{g}^{-1}$ d.wt.) at RDN and RDN-25\%. Whereas, amylose content was higher in BW 9183, GLU 1101, BW 8989 genotypes ( 23.8 $\mathrm{mg} \mathrm{g}^{-1}$ d.wt.) at RDN-25\% while amylopectin content was more in BW 9183 and BW 8989 genotypes ( 49.1 $\mathrm{mg} \mathrm{g}^{-1}$ d.wt.) over other genotypes at $\mathrm{RDN}+25 \%$ and $\mathrm{RDN}+50 \%$.

Interpretation: Due to consistent performance of GLU 1101, GLU 1356, PBW 590, BW 9183 and PH-132-4836 genotypes at sub-optimal nitrogen dose, these genotypes hold future potential for developing new cultivars with better grain quality parameters.

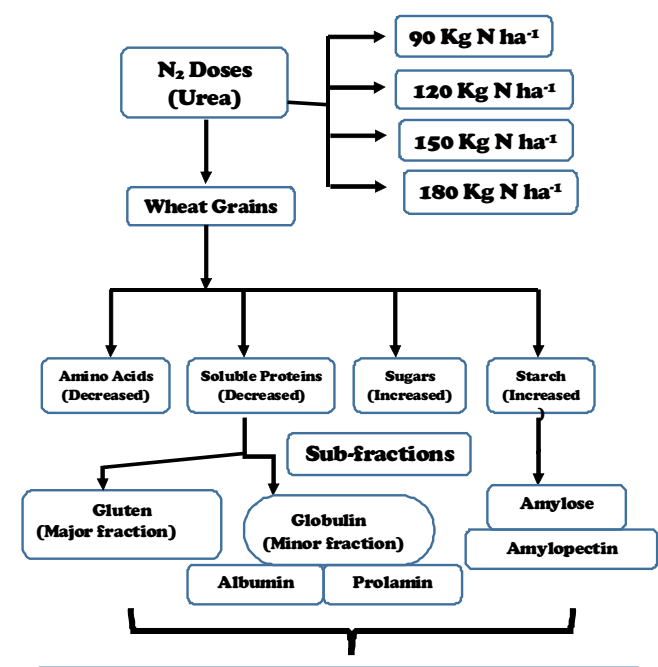

GLU1101, GLU1356, PBW590, BW9183, PH-132-4836 showed high grain protein at $90 \mathrm{Kg} \mathrm{N} \mathrm{ha-1}$ 


\section{Introduction}

Wheat (Triticum aestivum L.) is one of the three major cereals dominating agricultural world today. It accounts for majority of food products used for human diets. The quality of wheat based food products and the processing of wheat flour are strongly related to the composition of proteins and starch.

Wheat grain proteins is an important trait and plays a crucial role in forming a strong, cohesive dough that will retain gas and produce light baked products (Abedi et al., 2011). These properties make wheat suitable for the preparation of a great diversity of food products: breads, noodles, pasta, cookies, cakes, pastries and many other foods. The mature wheat grains comprises of $18-20 \%$ proteins which are further classified into four categories on the basis of their solubility- albumin (water), globulin (salt), gluten (alkali) and prolamin (propanol) (Osborne 1907). Gluten is large complex proteins composed of glutenin and gliadins, which is important for baking quality because of their impact on water absorption capacity of the dough. Its elasticity and extensibility can affect wheat flour quality extensively (Torbica et al., 2007). Albumin and globulin probably have a critical role in flour quality, while they also have dual role as nutrient reserves for the germinating embryo (Singh and Skerritt, 2001).

Starches with varying pasting characteristics are of major concern for food processing because of their potential to modify the texture and quality of the end use based products. It also serves as a source of carbon during yeast fermentation in bread making, in setting of the bread loaf and in retrogradation during storage (Singh et al., 2010). Starch is divided into two broad categories: amylose and amylopectin. Amylose consist of glucose units having linear chain linked by $a-1,4$ linkage, while amylopectin has an additional a-1,6 linkages. The content of amylose varies from 20 to $30 \%$, whereas amylopectin constitutes about $75 \%$ of cereal starches. High amylose content (> $40 \%$ ) in starch is used as thickeners and as strong gelling agents while amylopectin content in starch improves homogeneity, stability, texture of gelled starch that enhances the stability of starch gel at frosting and defrosting of frozen foods (Massaux et al., 2008).

Wheat is preferably grown for bread and other flour products because of its supreme baking performance (Dewettinck et al., 2008). The wheat quality characteristics are usually influenced by genotype, environmental factors and the interaction between genotype and environment. Nitrogen nutrition, an indispensible factor for wheat production during growth especially through the grain filling period is identified as a major constraint to wheat grain quality world wide (Dupont and Altenbach., 2003).

Albumin and globulin are controlled merely by genotypes than nitrogen treatment whereas prolamin and glutenin are largely determined by nitrogen (Fuertes-Mendizabal et al., 2010).
Reports indicate that different nitrogen rates can cause changes in the total amount of different grain proteins. Infact, the composition of proteins fractions has found to be much more affected by nitrogen management than temperature (Hurkman et al., 2013). In other words, high nitrogen supply increases grain proteins concentration linearly while grain yield response to added nitrogen had a diminishing return relationship. Apparently, when nitrogen very limiting, small nitrogen addition resulted in greater grain yield with decreased proteins concentration caused by dilution of the plant nitrogen. Thus, nitrogen nutrition is the main factor affecting storage proteins as well as the technological quality of the grain. Nitrogen nutrition is also considered as the third most environmental factor influencing starch composition and properties (Xiong et al., 2014). Zadeh et al. (2013) showed that a moderate reduction in $\mathrm{N}$ lead to small increases in starch content in wheat. Increased $\mathrm{N}$ fertilization improves amylopectin content while content of amylose in rice varieties decreases. Thus, nitrogen influences both proteins and starch composition (Kindred et al., 2008).

Although nitrogen application greatly influences starch and proteins composition, very little information is available on the effect of nitrogen fertilizer on protein sub fractions and starch components with little emphasis on quality characteristics. However, none of the earlier studies have reported the effects of different doses of nitrogen application on grain quality parameters such as starch (amylose and amylopectin) and proteins (albumin, globulin, gluten and prolamin) sub-components of wheat. Therefore, the aim of the study was to evaluate the genotypic variation based on starch and protein accumulation under different doses of nitrogen.

\section{Materials and Methods}

Plants materials and nitrogen treatment : Seeds of nine wheat (Triticum aestivum L.) genotypes viz: PBW 621, PBW 590, PBW 509, PBW 550, BW 9183, BW 8989, GLU 1101, GLU 1356 and $\mathrm{PH} 132-4836$ were raised in the experimental area of Department of Plant Breeding and Genetics, Punjab Agricultural University, Ludhiana, Punjab, India. The crop was raised under different doses of nitrogen - optimal $\mathrm{N}$ dose i.e. recommended dose of $\mathrm{N}$ (RDN, $120 \mathrm{Kg} \mathrm{N}^{-1} \mathrm{C}^{-1}$ ), suboptimal $\mathrm{N}$ dose (RDN-25\%, $90 \mathrm{Kg} \mathrm{N}$ ha$\left.{ }^{1}\right)$ and supra-optimal $\mathrm{N}$ doses RDN+25\% (150 kg N ha- $\left.{ }^{-1}\right)$ and $\mathrm{RDN}+50 \%$ (180 kg N ha ${ }^{-1}$ ) in plots consisting of 4 rows of $1 \mathrm{~m}$ each. Row to row spacing was maintained at 9 inches while spacing between the plots was $40 \mathrm{~cm}$. Nitrogen was applied as urea. Basal dose of di-ammonium phosphate and NPK was added at the time of sowing. Mature grains were used for analysis of grain quality parameters analysis. There were three replications for each parameter.

Determination of free sugars, amino acid, starch and proteins : Free sugars were extracted sequentially from mature grains with $80 \%$ and $70 \%$ EtOH from ethanol-preserved samples. The test 
extracts were clarified with basic lead acetate and from these extracts and concentration of total sugars were determined (Dubois et al., 1956). From sugars free grain samples, starch was determined by perchloric acid method as described by (Dubois et al., 1956). Total free amino acids were extracted and determined as described earlier by Lee and Takahashi (1966). Soluble proteins extracted in $0.1 \mathrm{NaOH}$ and precipitated with trichloroacetic acid and estimated by the method of Lowry et al. (1951).

Determination of proteins sub-fractions : The sequential extraction of different protein fractions in the whole grain flour was carried out by extracting wheat flour $(100 \mathrm{mg})$ sequentially with 5 $\mathrm{ml}$ of $1 \mathrm{~N} \mathrm{NaOH}$ for albumin, $5 \mathrm{ml}$ of $10 \% \mathrm{NaCl}$ for globulin, $5 \mathrm{ml}$ of $55 \%$ propanol for prolamin and $5 \mathrm{ml}$ of distilled water for gluten. The extractions were carried out on magnetic stirrer for $15 \mathrm{~min}$ at room temperature and the suspensions were centrifuged for 20 min at $15,000 \mathrm{xg}$. To a $2 \mathrm{ml}$ of supernatant, $2 \mathrm{ml}$ chilled $20 \%$ TCA was added and mixed thoroughly. After aging for $1 \mathrm{hr}$ at $4^{\circ} \mathrm{C}$, the contents were again centrifuged at $14,000 \mathrm{xg}$ for $15 \mathrm{~min}$ and the precipitates were dissolved in $0.5 \mathrm{~N} \mathrm{NaOH}$ for proteins subfractions estimation (Lowry et al., 1951).

Determination of amylose and amylopectin content : The sequential extraction of starch granules i.e., small (amylose) and large (amylopectin) was done by the method of Takeda et al. (1989). Further, separation of amylose and amylopectin from mature grain samples was carried out by the method of Peng et al (1999). Amylose and amylopectin was estimated colorimetrically according to Chrastil (1987).

Statistical analysis : Values reported are average of triplicate observations and was subjected to analysis of variance (ANOVA). Correlation was also carried out for determining the relationship between different variables.

\section{Results and Discussion}

The level of soluble protein content not only reflects the level of plant nitrogen metabolism, but is also regarded as an important indicator of degree of leaf senescence, especially in wheat grain filling stage (Dupont and Altenbach, 2003). The major effect of $\mathrm{N}$ fertilization on wheat grain quality characteristics is exerted through changes in the grain final $\mathrm{N}$ content (FuertesMendizabal et al., 2010). Protein concentration in flour is the main quality determinant for wheat. In the present study, the effect of different doses of nitrogen on starch and protein accumulation was analysed in different wheat genotypes.

Metabolites (amino acids, proteins, sugars and starch) in nine wheat genotypes seeds as influenced by different doses of nitrogen are given in Table 1. Application of increasing levels of $\mathrm{N}$ i.e., RDN+25\% (150 kg N ha $\left.{ }^{-1}\right)$ and RDN+50\% (180 kg N ha $\left.{ }^{-1}\right)$ led to an increased content of amino acids and proteins whereas RDN-25\% (90 kg N ha-1) and RDN, (120 kg N ha $\left.{ }^{-1}\right)$ doses resulted in decreased content in wheat seeds. Amino acids content varied with respect to genotypes but were comparatively higher in genotypes GLU 1101 (2.51 mg g ${ }^{-1}$ d.wt.) and GLU 1356 (2.49 mg $\mathrm{g}^{-1}$ d.wt.) due to $\mathrm{Gpc}-\mathrm{B} 1$ gene indicating higher translocation of $\mathrm{N}$ from the vegetative organs to sink tissue, and thus influencing grain proteins and amino-acids accumulation over other genotypes. In rice varieties, free amino $\mathrm{N}$-content increased with increasing application of $\mathrm{N}$ (Farooq et al., 2012). Maximum protein content was observed in GLU 1356 at RDN+25\% (136.7 $\mathrm{mg} \mathrm{g}^{-1}$ d.wt.) and RDN+50\% (141.7 $\mathrm{mg} \mathrm{g}^{-1}$ d.wt.) as compared to RDN-25\% (135.8 $\mathrm{mg} \mathrm{g}^{-1}$ ) (Table 1). In maize, application of highest $300 \mathrm{Kg} \mathrm{N}^{-1}{ }^{-1}$ rather than $75 \mathrm{Kg} \mathrm{N}^{-1}$ led to increased proteins content (Khan et al., 2008). Thus, under low $\mathrm{N}$ conditions, the amino acids content decreased significantly and continually during leaf development. Slight decrease in amino acids content under low $\mathrm{N}$ supply could be interpreted as dilution of a stable organic $\mathrm{N}$ pool by increasing leaf volume. Higher $\mathrm{N}$ supply caused an overall increase in amino acids content and the large part of which is stored in vacuole (Masclaux et al., 2010). Thus, $\mathrm{N}$ fertilization can be used for nutritional improvement of cereals by increasing and maintaining proteins and essential amino acids content.

Carbohydrate distribution within plant is also affected by $\mathrm{N}$ supply which strongly influences the processes of carbon assimilation, allocation and partitioning (Mehta et al., 2011; Bala et al., 2016). Sugars content decreased at lower $\mathrm{N}$ doses i.e. RDN-25\% and RDN+25\% over RDN except in cv BW 8989. Maximum content of sugars and starch was observed in genotypes PBW 550 (20.3 $\mathrm{mg} \mathrm{g}^{-1}$ d.wt., 73.31\%) and BW 9183 (19.7 $\mathrm{mg} \mathrm{g}^{-1}$ d.wt., $73.31 \%$ ) at RDN in contrast with amino acid and proteins content which was comparatively less thereby showing negative correlation (Table 1). These results were in accordance with studies done in sweet sorghum indicating an increase in sugars content with increasing level of $N$ (Almodares et al., 2008). Infact, N fertilizer affects distribution of A-type and B-type starch granules which affects the content and proportion of starch in wheat grains (Xiong et al., 2014). Correspondingly, distribution of starch granules is regulated by timing and amount of $\mathrm{N}$ fertilizer applied.

Accumualtion of protein subfractions in mature grains of nine wheat genotypes as influenced by different doses of nitrogen are given in Table 2. Amongst different proteins, the concentration of gluten was highest over prolamin, globulin and albumin. A significant increase in gluten, globulin, albumin and prolamin content was observed with $\mathrm{RDN}+50 \%$ and $\mathrm{RDN}+25 \%$ as compared to RDN. Gluten, confers properties of elasticity and extensibility that are essential for functionally of wheat flours (Torbica et al., 2007). The range of gluten content in different genotypes were in the following order: PBW 590 (53.2 $\mathrm{mg} \mathrm{g}^{-1}$ d.wt.) > PH-132-4836 (52.7 mg g ${ }^{-1}$ d.wt.) > GLU 1101 (52.5 mg g ${ }^{-1}$ d.wt.) and PBW 509 (52.3 $\mathrm{mg} \mathrm{g}^{-1}$ d.wt.) at RDN $+50 \%$. Globulin is 
Table 1: Effect of different doses of nitrogen on wheat grains metabolites

\begin{tabular}{|c|c|c|c|c|c|}
\hline Genotypes & $\begin{array}{l}\text { Nitrogen application } \\
\left(\mathrm{kg} \mathrm{N} \mathrm{ha}^{-1}\right)\end{array}$ & $\begin{array}{l}\text { Amino acids } \\
\text { (mg g-1 d.wt.) }\end{array}$ & $\begin{array}{l}\text { Soluble proteins } \\
\text { (mg g }{ }^{-1} \text { d.wt.) }\end{array}$ & $\begin{array}{l}\text { Sugars } \\
\text { (mg g }{ }^{-1} \text { d.wt.) }\end{array}$ & $\begin{array}{l}\text { Starch } \\
(\%)\end{array}$ \\
\hline \multirow[t]{4}{*}{ PBW 621} & $\mathrm{~T}_{1}$ & 0.71 & 121.9 & 14.7 & 63.97 \\
\hline & $\mathrm{T}_{2}$ & 1.11 & 139.3 & 15.1 & 71.06 \\
\hline & $\mathrm{T}_{3}$ & 2.17 & 141.6 & 14.7 & 69.17 \\
\hline & $\mathrm{T}_{4}$ & 2.45 & 142.7 & 14.8 & 66.50 \\
\hline \multirow[t]{4}{*}{ PBW 590} & $\mathrm{~T}_{1}$ & 0.60 & 110.5 & 15.3 & 64.61 \\
\hline & $\mathrm{T}_{2}$ & 1.03 & 122.3 & 16.5 & 69.82 \\
\hline & $\mathrm{T}_{3}$ & 2.23 & 122.7 & 15.8 & 69.75 \\
\hline & $\mathrm{T}_{4}$ & 2.27 & 126.5 & 15.9 & 66.48 \\
\hline \multirow[t]{4}{*}{ PBW 509} & $\mathrm{~T}_{1}^{4}$ & 0.71 & 105.5 & 15.7 & 65.19 \\
\hline & $\mathrm{T}_{2}$ & 0.75 & 114.0 & 16.9 & 71.81 \\
\hline & $\mathrm{T}_{3}$ & 2.40 & 114.3 & 16.4 & 71.69 \\
\hline & $\mathrm{T}_{4}$ & 2.50 & 136.7 & 16.1 & 68.07 \\
\hline \multirow[t]{4}{*}{ BW 9183} & $\mathrm{~T}_{1}$ & 0.67 & 103.9 & 17.9 & 66.39 \\
\hline & $\mathrm{T}_{2}$ & 0.69 & 106.7 & 19.7 & 73.31 \\
\hline & $\mathrm{T}_{3}$ & 1.89 & 106.6 & 18.9 & 73.29 \\
\hline & $\mathrm{T}_{4}$ & 2.11 & 116.9 & 18.2 & 68.30 \\
\hline \multirow[t]{4}{*}{ BW 8989} & $\mathrm{~T}_{1}$ & 0.63 & 96.7 & 18.7 & 65.63 \\
\hline & $\mathrm{T}_{2}$ & 0.72 & 116.1 & 12.3 & 72.27 \\
\hline & $\mathrm{T}_{3}$ & 2.14 & 106.3 & 19.8 & 72.13 \\
\hline & $\mathrm{T}_{4}$ & 1.91 & 121.5 & 19.5 & 68.34 \\
\hline \multirow[t]{4}{*}{ PBW550 } & $\mathrm{T}_{1}^{4}$ & 0.67 & 101.7 & 18.1 & 64.61 \\
\hline & $\mathrm{T}_{2}$ & 0.63 & 101.5 & 20.3 & 73.31 \\
\hline & $\mathrm{T}_{3}$ & 2.15 & 101.9 & 19.5 & 71.43 \\
\hline & $\mathrm{T}_{4}$ & 2.05 & 101.7 & 18.3 & 68.28 \\
\hline \multirow[t]{4}{*}{ GLU 1101} & $\mathrm{~T}_{1}^{4}$ & 0.60 & 109.7 & 15.2 & 64.09 \\
\hline & $\mathrm{T}_{2}$ & 0.20 & 126.1 & 16.1 & 69.41 \\
\hline & $\mathrm{T}_{3}$ & 2.14 & 125.8 & 15.6 & 69.23 \\
\hline & $\mathrm{T}_{4}$ & 2.51 & 126.3 & 5.50 & 66.80 \\
\hline \multirow[t]{4}{*}{ GLU 1356} & $\mathrm{~T}_{1}$ & 0.99 & 135.8 & 14.1 & 64.21 \\
\hline & $\mathrm{T}_{2}$ & 0.98 & 136.3 & 15.1 & 69.81 \\
\hline & $\mathrm{T}_{3}$ & 2.41 & 136.7 & 14.6 & 69.79 \\
\hline & $\mathrm{T}_{4}$ & 2.49 & 141.7 & 14.5 & 66.24 \\
\hline \multirow[t]{4}{*}{ PH132-4836 } & $\mathrm{T}_{1}^{4}$ & 0.64 & 113.7 & 14.7 & 65.13 \\
\hline & $\mathrm{T}_{2}$ & 0.86 & 116.5 & 16.1 & 71.27 \\
\hline & $\mathrm{T}_{3}$ & 2.03 & 116.9 & 15.4 & 71.23 \\
\hline & $\mathrm{T}_{4}$ & 2.06 & 136.3 & 15.2 & 67.23 \\
\hline \multirow[t]{2}{*}{$\mathrm{CD}(5 \%)$} & A-N Doses & A- 0.124 & A- 0.500 & A- 0.362 & A- 0.237, \\
\hline & B-Genotypes & $\begin{array}{l}B=0.264, \\
A B=0.524\end{array}$ & $\begin{array}{l}B=1.061 \\
A B-2.127\end{array}$ & $\begin{array}{l}B=0.767 \\
A B=1.135\end{array}$ & $\begin{array}{l}B=0.504, \\
A B-1.008\end{array}$ \\
\hline
\end{tabular}

$\left.\mathrm{T}_{1}-\mathrm{RDN}-25 \%\left(90 \mathrm{~kg} \mathrm{Nha}^{-1}\right), \mathrm{T}_{2}-\mathrm{RDN}\left(120 \mathrm{~kg} \mathrm{Nha}^{-1}\right)\right] ; \mathrm{T}_{3}-\mathrm{RDN}+25 \%\left(150 \mathrm{~kg} \mathrm{Nha}^{-1}\right) ; \mathrm{T}_{4}-\mathrm{RDN}+50 \%\left(180 \mathrm{~kg} \mathrm{Nha}^{-1}\right)$

another important proteins fraction from nutritional point of view as it determines the bread making quality of wheat. Globulin content was found to be maximum in genotypes GLU 1101 (34.8 $\mathrm{mg} \mathrm{g}^{-1}$ d.wt.), $\mathrm{PH}-132-4836$ (33.8 $\mathrm{mg} \mathrm{g}^{-1}$ d.wt.) and BW 8989 (33.5 $\mathrm{mg} \mathrm{g}^{-1} \mathrm{~d}$.wt.) at $\mathrm{RDN}+50 \%$. This increase was almost significant at all N-levels. Maximum content of albumin ( $31.2 \mathrm{mg} \mathrm{g}^{-1} \mathrm{~d}$.wt.) and prolamin (32.0 $\mathrm{mg} \mathrm{g}^{-1} \mathrm{~d}$.wt.) was observed in PBW 550 genotype at RDN+50\% (Table 2). Proteins sub-fractions decreased with decrease in nitrogen application indicating, thereby that maximum albumin and prolamin content was found in wheat seeds treated with $\mathrm{RDN}+50 \%$ followed by $\mathrm{RDN}+25 \%$ and RDN dose, whereas minimum albumin and prolamin content was found in mature seeds treated with RDN-25\% and RDN, respectively. Results of the study indicated that increase in nitrogen doses led to consistent increase in different fractions of proteins. Similarily, among various treatments of nitrogen doses in spring triticale grain, highest protein concentration subfractions was recorded with higher doses of nitrogen (Wojtkowaiki etal., 2013).

Starch sub-fractions (amylose and amylopectin) are other important characters of wheat grain quality evaluation for 
Table 2 : Effect of different doses of nitrogen on proteins sub-fractions and starch sub-components in wheat grains

\begin{tabular}{|c|c|c|c|c|c|c|c|}
\hline Genotypes & $\begin{array}{l}\text { Nitrogen applicaton } \\
\left(\mathrm{kg} \mathrm{N} \mathrm{ha}^{-1}\right)\end{array}$ & $\begin{array}{l}\text { Gluten } \\
\text { (mg g }{ }^{-1} \text { d.wt.) }\end{array}$ & $\begin{array}{l}\text { Albumin } \\
\text { (mg g-1 d.wt.) }\end{array}$ & $\begin{array}{l}\text { Globulin } \\
\text { (mg g }{ }^{-1} \text { d.wt.) }\end{array}$ & $\begin{array}{l}\text { Prolamin } \\
\text { (mg g }{ }^{-1} \text { d.wt.) }\end{array}$ & $\begin{array}{l}\text { Amylose } \\
\text { (mg g-1 d.wt.) }\end{array}$ & $\begin{array}{l}\text { Amylopectin } \\
\text { (mg g }{ }^{-1} \text { d.wt.) }\end{array}$ \\
\hline \multirow[t]{4}{*}{ PBW 621} & $\mathrm{~T}_{1}$ & 50.3 & 27.5 & 27.3 & 27.4 & 22.97 & 46.35 \\
\hline & $\mathrm{T}_{2}$ & 51.4 & 27.6 & 28.1 & 27.8 & 22.53 & 48.75 \\
\hline & $\mathrm{T}_{3}$ & 51.9 & 28.8 & 31.1 & 28.0 & 22.17 & 47.93 \\
\hline & $\mathrm{T}_{4}$ & 52.5 & 28.9 & 33.7 & 28.3 & 22.06 & 45.73 \\
\hline \multirow[t]{4}{*}{ PBW 590} & $\mathrm{~T}_{1}$ & 51.3 & 26.5 & 26.2 & 27.2 & 23.61 & 47.25 \\
\hline & $\mathrm{T}_{2}$ & 51.5 & 27.0 & 26.3 & 28.0 & 23.52 & 48.28 \\
\hline & $\mathrm{T}_{3}$ & 52.4 & 28.2 & 29.0 & 28.4 & 22.57 & 47.75 \\
\hline & $\mathrm{T}_{4}$ & 53.2 & 28.8 & 31.1 & 29.2 & 21.82 & 46.61 \\
\hline \multirow[t]{4}{*}{ PBW 509} & $\mathrm{~T}_{1}$ & 50.9 & 26.8 & 25.7 & 27.2 & 24.19 & 48.18 \\
\hline & $\mathrm{T}_{2}$ & 51.0 & 28.0 & 26.7 & 27.4 & 23.89 & 49.07 \\
\hline & $\mathrm{T}_{3}^{2}$ & 51.9 & 28.4 & 28.7 & 27.5 & 23.69 & 48.89 \\
\hline & $\mathrm{T}_{4}$ & 52.3 & 29.0 & 31.8 & 28.4 & 23.33 & 46.95 \\
\hline \multirow[t]{4}{*}{ BW 9183} & $\mathrm{~T}_{1}$ & 51.2 & 28.1 & 26.5 & 27.0 & 25.39 & 48.78 \\
\hline & $\mathrm{T}_{2}$ & 51.3 & 28.3 & 28.1 & 28.0 & 25.37 & 50.09 \\
\hline & $\mathrm{T}_{3}$ & 51.4 & 28.5 & 28.2 & 28.2 & 25.24 & 49.81 \\
\hline & $\mathrm{T}_{4}$ & 51.9 & 29.2 & 32.6 & 29.5 & 24.97 & 48.39 \\
\hline \multirow[t]{4}{*}{ BW 8989} & $\mathrm{~T}_{1}^{4}$ & 51.0 & 27.9 & 27.1 & 27.6 & 24.63 & 49.36 \\
\hline & $\mathrm{T}_{2}$ & 51.1 & 28.5 & 27.9 & 28.1 & 24.35 & 49.81 \\
\hline & $\mathrm{T}_{3}$ & 51.4 & 28.6 & 28.6 & 28.3 & 24.13 & 49.53 \\
\hline & $\mathrm{T}_{4}$ & 51.8 & 29.0 & 33.5 & 28.6 & 23.87 & 47.25 \\
\hline \multirow[t]{4}{*}{ PBW550 } & $\mathrm{T}_{1}^{4}$ & 50.4 & 30.5 & 28.4 & 29.6 & 22.83 & 47.74 \\
\hline & $\mathrm{T}_{2}$ & 51.3 & 30.8 & 28.8 & 30.5 & 22.61 & 48.93 \\
\hline & $\mathrm{T}_{3}$ & 52.1 & 31.0 & 29.6 & 31.4 & 22.43 & 48.57 \\
\hline & $\mathrm{T}_{4}$ & 52.2 & 31.2 & 31.1 & 32.0 & 22.14 & 46.63 \\
\hline \multirow[t]{4}{*}{ GLU 1101} & $\mathrm{~T}_{1}$ & 51.5 & 26.8 & 27.1 & 28.0 & 22.14 & 47.23 \\
\hline & $\mathrm{T}_{2}$ & 51.5 & 28.0 & 28.2 & 28.4 & 21.87 & 48.14 \\
\hline & $\mathrm{T}_{3}$ & 52.0 & 28.4 & 29.4 & 30.7 & 21.63 & 47.74 \\
\hline & $\mathrm{T}_{4}$ & 52.5 & 31.2 & 34.8 & 30.9 & 21.41 & 45.93 \\
\hline \multirow[t]{4}{*}{ GLU 1356} & $\mathrm{~T}_{1}^{4}$ & 51.1 & 27.1 & 26.5 & 26.6 & 22.32 & 47.52 \\
\hline & $\mathrm{T}_{2}$ & 51.5 & 27.2 & 27.1 & 26.9 & 22.16 & 48.78 \\
\hline & $\mathrm{T}_{3}$ & 52.0 & 27.7 & 29.3 & 27.8 & 21.97 & 48.17 \\
\hline & $\mathrm{T}_{4}$ & 52.4 & 28.9 & 31.6 & 28.0 & 21.61 & 46.21 \\
\hline \multirow[t]{4}{*}{ PH132-4836 } & $\mathrm{T}_{1}$ & 51.8 & 28.3 & 26.9 & 28.3 & 24.27 & 47.18 \\
\hline & $\mathrm{T}_{2}$ & 52.1 & 29.0 & 27.2 & 28.7 & 24.13 & 48.25 \\
\hline & $\mathrm{T}_{3}$ & 52.5 & 30.2 & 28.7 & 31.3 & 24.07 & 48.23 \\
\hline & $\mathrm{T}_{4}$ & 52.7 & 31.0 & 33.8 & 31.9 & 23.86 & 46.97 \\
\hline \multirow[t]{2}{*}{$\mathrm{CD}(5 \%)$} & A-NDoses & A- 0.117, & A- 0.612 & A-0.691, & A- 0.652 & A-0.148, & A-0.386, \\
\hline & B-Genotypes & $\begin{array}{l}\text { B- } 0.236 \\
\text { AB }-0.473\end{array}$ & $\begin{array}{l}\text { B- } 0.129 \\
\text { AB }-1.259\end{array}$ & $\begin{array}{l}B-0.146 \\
A B-1.293\end{array}$ & $\begin{array}{l}\text { B }-0.139, \\
A B-1.278\end{array}$ & $\begin{array}{l}\text { B- } 0.315 \\
A B=0.631\end{array}$ & $\begin{array}{l}B-0.819 \\
A B-1.164\end{array}$ \\
\hline
\end{tabular}

$\left.\mathrm{T}_{1}-\mathrm{RDN}-25 \%\left(90 \mathrm{~kg} \mathrm{Nha}^{-1}\right) ; \mathrm{T}_{2}-\mathrm{RDN}\left(120 \mathrm{~kg} \mathrm{~N} \mathrm{ha}^{-1}\right)\right] ; \mathrm{T}_{3}-\mathrm{RDN}+25 \%\left(150 \mathrm{~kg} \mathrm{Nha}^{-1}\right) ; \mathrm{T}_{4}-\mathrm{RDN}+50 \%\left(180 \mathrm{~kg} \mathrm{Nh}^{-1}\right)$

pasta products and these components increased in BW 9183, BW 8989 and PH-132-4836 genotypes (Table 2), indicates preferential utilization of these genotypes for nutritional and technological properties (including adhesion, foam strengthening, gelling, glazing, moisture retention, stabilizing and texturizing) of wheat. The application of $\mathrm{N}$ fertilizer altered the starch characteristics in wheat grains. Highest amylose content was found in the genotype BW 9183 (25.39\%) followed by BW 8989 (24.63\%) and PH-132-4836 (24.27\%) at RDN-25\%, whereas lowest amylose content was observed in genotype GLU $1101(21.41 \%)$ at $\mathrm{RDN}+50 \%$ thus representing that with increase in nitrogen doses, amylose content decreases, respectively.

Maximum amylopectin content was observed in genotype BW 9183 (50.09\%) followed by BW 8989 (49.81\%) and PBW 509 (49.07\%) at optimal dose of $\mathrm{N}$ over other genotypes. Starch sub-fractions depicting that amylopectin was significantly affected by nitrogen doses, whereas amylose content was in significantly affected by nitrogen doses. Thus, it was inferred that with increase in the amount of nitrogen fertilizer, activation of starch branching enzymes might have resulted in increase in 
Table 3 : Correlation coefficients between amnio acids, proteins, sugars, starch, proteins sub-fractions and starch sub-components in mature grains

\begin{tabular}{|c|c|c|c|c|c|c|c|c|c|}
\hline & Amino acids & Proteins & Sugars & Starch & Gluten & Albumin & Globulin & Prolamin & Amylose \\
\hline Protein & 0.787 & & & & & & & & \\
\hline Sugars & -0.44 & -0.813 & & & & & & & \\
\hline Starch & -0.559 & -0.798 & 0.881 & & & & & & \\
\hline Gluten & 0.055 & 0.281 & -0.493 & -0.497 & & & & & \\
\hline Albumin & -0.600 & -0.608 & 0.471 & 0.409 & 0.008 & & & & \\
\hline Globulin & -0.344 & 0.063 & -0.163 & -0.135 & -0.206 & 0.444 & & & \\
\hline Prolamin & -0.658 & -0.530 & 0.215 & 0.151 & 0.309 & 0.912 & 0.431 & & \\
\hline Amylose & -0.434 & -0.513 & 0.611 & 0.834 & -0.188 & 0.045 & -0.306 & -0.115 & \\
\hline Amylopectin & -0.439 & -0.642 & 0.753 & 0.901 & -0.585 & -0.058 & -0.268 & -0.177 & 0.827 \\
\hline
\end{tabular}

amylopectin percentage decreasing amylose content. Similar results were reported in rice varieties by Li et al. (2010) indicating a negative correlation between nitrogen rate and amylose content.

A pooled correlation analysis was done for various biochemical parameters studied at different doses of nitrogen. Total sugars were significantly but negatively correlated with amino acids and proteins, while positively correlated with sugars and starch content (Table 3). All protein subfractions were positively correlated with amino acids and proteins, while negatively correlated with sugars and starch. Amylose and amylopectin was negatively correlated with amino acids and proteins while positively correlated with sugars and starch content indicating, thereby all the metabolites of mature grains were significantly correlated with each other.

In conclusion, distribution of proteins, starch and their sub fractions in wheat genotypes are significantly affected by different doses of nitrogen, and genotypic response play a vital role in enhancing proteins content thereby improving grain quality traits.

\section{Acknowledgment}

Thanks are due to the Department of Plant Breeding and Genetics for providing plant material to carry out the present investigation.

\section{References}

Abedi, T., A. Alemzadeh and S.A. Kazemeini: Wheat yield and grain protein response to nitrogen amount and timing. Aust. J. Crop Sci., 5, 330-336 (2011).

Almodares, A., R. Taheri, I.M. Chung and M. Fathi: The effect of nitrogen and potassium fertilizers on growth parameters and carbohydrate contents of sweet sorghum cultivars. J. Environ. Biol., 29, 849-852 (2008).

Bala, S., B. Asthir and N.S. Bains: Activities of cell wall peroxidases in relation to lignification in six wheat (Triticum aestivum L.) genotypes under heat and drought stress. J. Environ. Biol., 37, 437-442 (2016).

Chrastil, J.: Improved colorimetric determination of amylose in starches or flours. Carbohydr. Res., 159, 154-158(1987).
Dewettinck, K., F. Van Bockstaele, B. Kuhne, D. Van de Walle, T.M. Courtens and X. Gellynck: Nutritional value of bread: Influence of processing, food interaction and consumer perception. J. Cereal Sci., 48, 243-257 (2008).

Dubois, M., D.A. Gilles, J.K. Hamiliton, P.A. Rebers and F. Smith: Colorimetric method for the determination of sugars and related substances. Anal. Chem., 28, 350-356 (1956).

Dupont, F.M. and S.B. Altenbach: Molecular and biochemical impacts of environmental factors on wheat grain development and proteins synthesis. J. Cereal Sci., 38, 133-146 (2003).

Faroog, M., A. Wahid and K.H.M. Siddique: Micronutrients application through seed treatments. J. Soil Sci. Plant Nutr., 12, 125-142 (2012).

Fuertes-Mendizabal, T., A. Aizpurua, M.B. Gonzalez-Moroand and J.M. Estavillo: Improving wheat breading making quality by splitting the $\mathrm{N}$ fertilizer rate. Eur. J. Agron., 33, 52-61 (2010).

Hurkman, W.J., C.K. Tanaka, W.H. Vensel, R. Thilmony and S.B. Altenbach: Comparative proteomic analysis of the effect of temperature and fertilizer on gliadin and glutenin accumulation in the developing endosperm and flour from Triticum aestivum L. cv. Butte 86. Proteome. Sci., 11, 8-11 (2013).

Khan, H.Z., M.A. Malikand and M.F. Saleem: Effect of rate and source of organic material on the production potential of spring maize (Zea mays L.). Pak. J. Agri. Sci., 45, 40-43 (2008).

Kindred, D.R., T.M.O. Verhoeven, R.M. Weightman, J.S. Swanston, R.C. Agu, J.M. Brosnan and R. Sylvester-Bradley: Effects of variety and fertilizer nitrogen on alcohol yield, grain yield, starch and protein content, and protein composition of winter wheat. J. Cereal Sci., 48, 46-57 (2008).

Lee, Y.P. and T. Takahashi: An improved colorimetric determination of amino acid with the use of ninhydrin. Anal. Biochem., 14, 71-77 (1966).

Li, X., H. Liu, Z. Jin, H. Liu, X. Huang, M. Xu and F. Zhang: Changes in activities of key enzymes for starch synthesis and glutamine synthetase in grains of progenies from a rice cross during grain filling. Rice Sci., 17, 243-246 (2010).

Lowry, O.H., N.J. Rosebrough, A.L. Farr and R.J. Randall: Proteins measurement with the folin phenol reagent. J. Biol. Chem., 193, 265-75 (1951).

Masclaux, C., D.F. Vedele, J. Dechorgnat, F. Chardon, L. Gaufichon and A. Suzuki: Nitrogen uptake, assimilation and remobilisation in plants: challenges for sustainable and productive agriculture. Ann. Bot., 105, 1141-1157 (2010).

Massaux, C., M. Sindic, J. Lenartz, G. Sinnaeve, B. Bodson, A. Falisse, P. Dardenne and C. Deroanne: Variations in physicochemical and 
functional properties of starches extracted from European soft wheat (Triticum aestivum L.): the importance to preserve the varietal identity. Carbohydr. Polymers, 71, 32-41 (2008)

Mehta, S., S. Bedi and K.K. Vashist: Performance of winter maize (Zea mays) hybrid to planting methods and nitrogen levels. Ind. J. Agric. Sci., 81, 50-54 (2011).

Osborne, J.B.: The proteins of the wheat Kernel. Washington, DC, Carnegie Institution of Washington (1907).

Peng, M., M. Gao, E.-S.M. Abdel-Aal, P. Hucl and R.N. Chibbar: Separation and characterization of A- and B-type starch granules in wheat endosperm. Cereal Chem.,76, 375-379 (1999).

Singh, J. and J.H. Skerritt: Chromosomal control of albumins and globulins in wheat grain assessed using different fractionation procedures. J. Cereal. Sci., 33, 163-181 (2001).

Singh, S., A.K. Gupta, S.K. Gupta and N. Kaur: Effect of sowing time on proteins quality and starch pasting characterstics in wheat (Triticum aestivum L.) genotypes grown under irrigated and rain- fed conditions. Food Chem., 122, 559-556 (2010).

Takeda, C., Y. Takeda and S. Hizukuri: Structure of amylo maize amylose. Cereal Chem., 66, 22-25 (1989).

Torbica, A., M. Antov, J. Mastilovic and D. Knezevic: The influence of changes in gluten complex structure on technological quality of wheat (Triticum aestivum L.). Food Res. Int., 40, 1038-1045 (2007).

Wojtkowiak, K., A. Stępień, M. Tańska, I. Konopka and S. Konopka: Impact of nitrogen fertilization on the yield and content of protein fractions in spring triticale grain. J. Agric. Res., 8, 3778-3783 (2013).

Xiong, F., X. Yua, L. Zhou, J. Zhang, Y. Jina, D. Lia and Z. Wang: Effect of nitrogen fertilizer on distribution of starch granules in different regions of wheat endosperm. The Crop J., 2, $46-54$ (2014).

Zadeh, A.N., E. Amiri, A. Shariffar, M. Tayefe and S. A. Hashemi: Effect of chemical and biological fertilizer on rice yield, growth and quality in paddy soil of Guilan province (Iran). J. Biodiver. Environ. Sci., 3, 61-68 (2013). 